\title{
Whole-exome sequencing identifies mutations in MYMK in a mild form of Carey-Fineman-Ziter syndrome
}

Hadil Alrohaif, MBChB, MSc, Ana Töpf, PhD, Teresinha Evangelista, MD, Monkol Lek, PhD, Daniel McArthur, PhD, and Hanns Lochmüller, MD, PhD

Neurol Genet 2018;4:e226. doi:10.1212/NXG.0000000000000226

Fusion of single-nucleated myoblasts is essential for the formation of multinucleated myocytes. Mechanisms that regulate myoblast fusion have been a focus of recent studies. ${ }^{1-4}$ Transmembrane protein 8 (TMEM8C), also known as myomaker, is a highly conserved muscle-specific transmembrane protein encoded by the MYMK gene. The protein is expressed during early muscle development. Mymk-null mice die soon after birth because of skeletal muscle deficiency. In these mice, skeletal muscle tissue is present but consists of a smaller number of mononucleated cells indicating failure of myoblast cell fusion. ${ }^{1}$ Myomaker is also expressed during muscle regeneration when it coordinates fusion of satellite cells with residual muscle fibers to regenerate the damaged muscle tissue. In the absence of myomaker, adult mouse muscle tissue is unable to regenerate. 5

In humans, mutations in the MYMK gene have recently been described in 8 individuals (aged 7-37 years) from 3 families with Carey-Fineman-Ziter syndrome (CFZS), a syndrome encompassing a congenital myopathy with marked facial weakness and Pierre Robin sequence, among other consistent features. ${ }^{6}$

Here, we report an additional and the oldest known patient-bearing mutations in the MYMK gene, identified through whole-exome sequencing (WES). We provide insights into disease progression, as well as ascertain features associated with the disorder.

\section{Clinical description}

The patient is a 69-year-old British white man with juvenile-onset proximal myopathy. Distal muscles were also affected, although to a lesser extent. Weakness is mild and symmetrical with muscle power in the range of $3-4 / 5$ for proximal muscles and $4-5 / 5$ in distal ones. The patient also had marked facial weakness, lagophthalmos, minimal limitations in horizontal gaze, dysphagia, and chronic gastrointestinal (GI) symptoms. He reports alternating diarrhea and constipation that have been attributed to irritable bowel syndrome. The patient recalls weakness from his late teens when he was not as able as his peers. He particularly recalls being unable to climb ropes or blow balloons. His symptoms were first brought to medical attention at the age of 19 years when he dislocated his right knee and was noted to have muscle weakness. Progression of the myopathy has not been remarkable, and he remains ambulant, with the main complaint being the GI symptoms that are associated with food avoidance and weight loss.

He had no cardiac or respiratory involvement, and his cognition was intact. The patient had mild dysmorphic features in the form of micrognathia, high-arched palate, and a prominent

\author{
Correspondence \\ Dr. Lochmüller \\ hanns.lochmuller@gmail.com
}



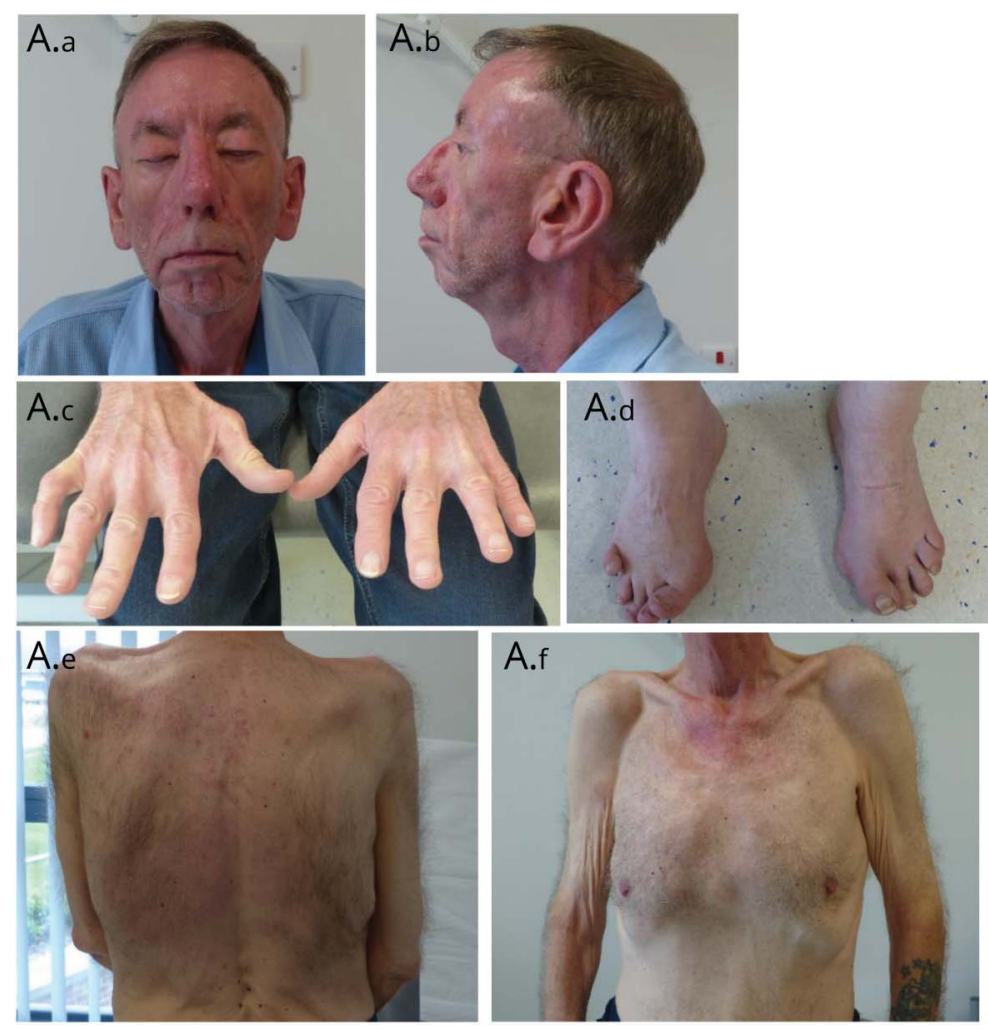

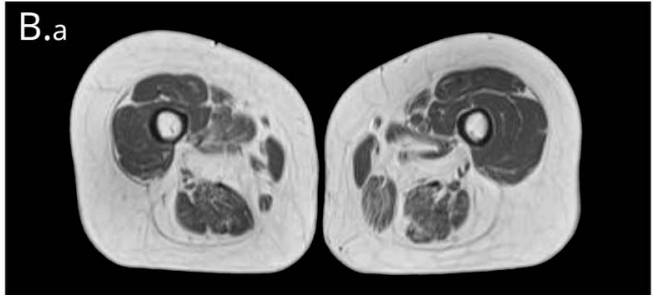

B.b

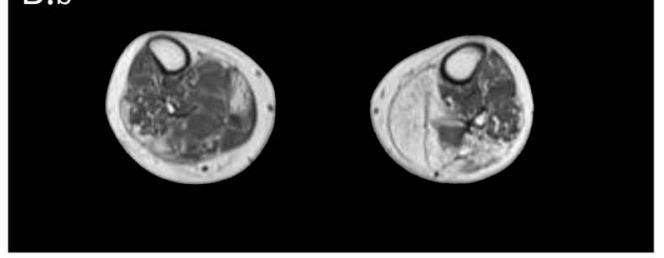

(A.a and A.b) Front and profile facial photographs demonstrating lagophthalmos (A.a, patient attempting lid closure), muscle hypoplasia, retrognathia, and broad nasal tip. (A.c and A.d) Wasting of intrinsic hand muscles and contracture deformities of the right little finger and the toes. (A.e, A.f) Scoliosis (A.e) and generalized muscle atrophy with pectoralis muscle hypoplasia (A.f). (B) T2-weighted MRIs of the thighs (B.a) showing severe fatty replacement of hamstrings, thigh adductors, and sartorius muscles, with relative sparing of the gracilis and quadriceps muscles bilaterally, and of the calves (B.b) showing asymmetric involvement with more marked fatty replacement in muscle of the right leg. Gastrocnemius and soleus muscles are severely affected, and the tibialis anterior on the right is relatively spared.

broad nasal tip (figure 1A). He also had spinal rigidity, scoliosis, bilateral pectoralis hypoplasia, and cryptorchidism. He also developed epilepsy, sensorineural hearing loss, unilateral cataracts, and glaucoma.

Serum creatinine kinase levels were mildly elevated (500-1,000 IU/L), and EMG showed a picture suggestive of a chronic mildly active necrotizing myopathy. MRI of his lower limbs showed selective and asymmetric involvement (figure 1B). Muscle biopsy showed nonspecific myopathic features, namely, fiber-size variation and occasional central nuclei (figure 2, A-F).

\section{Genetic study}

WES was performed at the Broad Institute of Harvard and MIT's Genomics Platform (Cambridge, MA) using $>250$ ng DNA ( $>2 \mathrm{ng} / \mu \mathrm{L})$ in a $38-\mathrm{Mb}$ targeted Illumina exome capture. Data were then analyzed on the Seqr interface (seqr.broadinstitute.org), initially using a candidate gene approach, consisting of a panel of 416 genes (musclegenetable.fr/, July 2016) known to be implicated in neuromuscular disorders, then searching for variants across the whole exome. This identified 2 heterozygous variants in the MYMK gene: c.271C>A (p.Pro91Thr) and c.553T >C
(p.Cys185Arg). Both variants were previously reported as disease-causing mutations. ${ }^{6}$

\section{Discussion}

Our patient presented with a mild slow progressing myopathy. Extraskeletal muscle manifestations pointed toward a syndromic myopathy rather than an isolated muscle disease. At the age of 69 years, he remains ambulant and shows slow progression of weakness. He shows no cardiac or respiratory involvement. The patient has a mild form of CFZS associated with $M Y M K$ mutations. Mainly proximal myopathy places $M Y M K$-associated CFZS in the differential diagnosis for the limb-girdle muscular dystrophies. Pierre Robin sequence and cryptorchidism (in males) are consistent features described in association with MYMK mutations, and both may be a consequence of muscle dysfunction in early development. A recent report associated CFZS with mutations in the STAC3 gene; a t-tubule protein involved in excitation-contraction coupling. Distinguishing features of STAC3-CFZS are short stature and malignant hyperthermia. ${ }^{7}$ Whether other clinical features present in our patient are a consequence of MYMK 

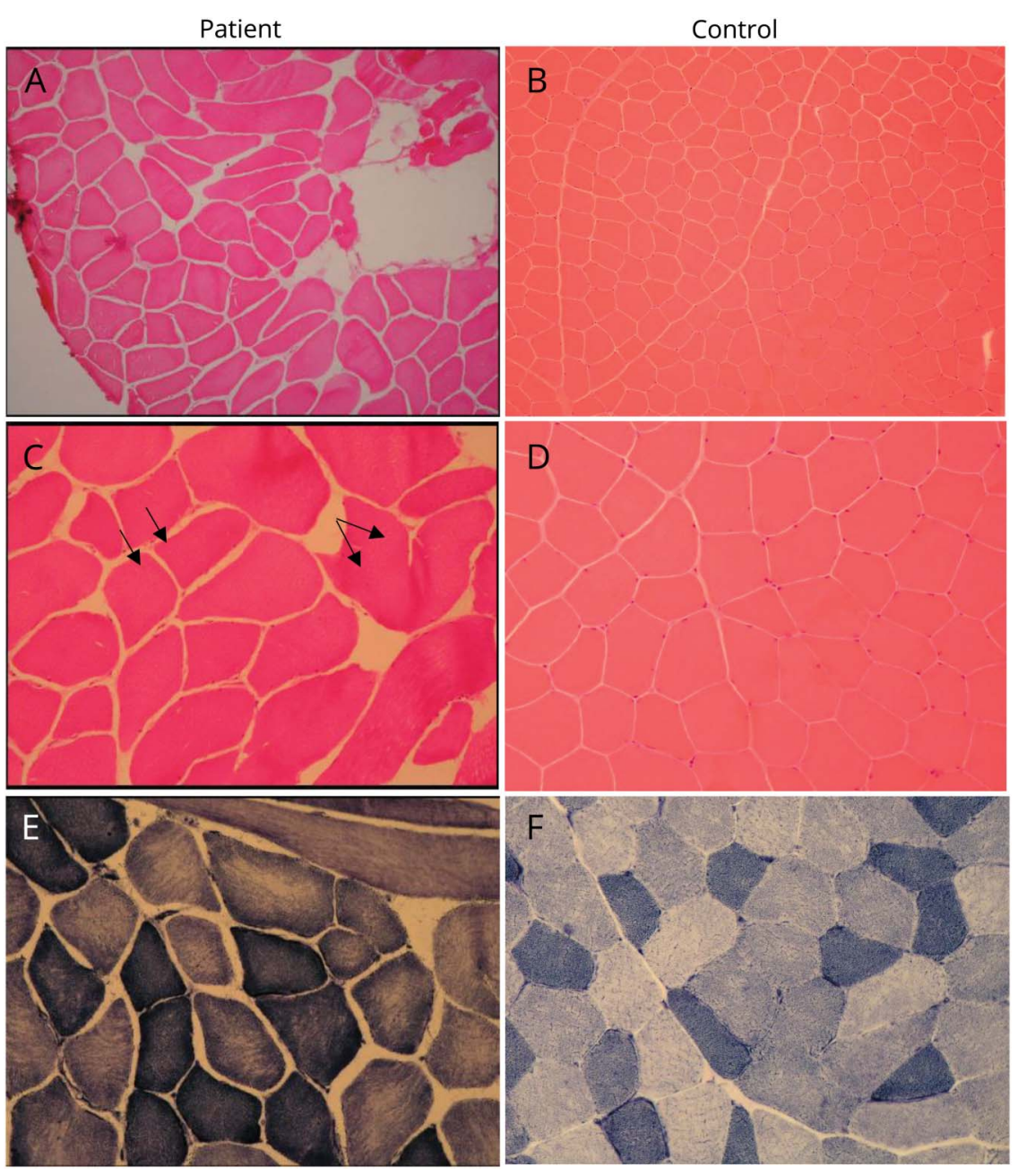

Patient images and control images. H\&E stain demonstrates fiber-size variation ( $A$ and $B ; H \& E$ $\times 100)$ and occasional internal nuclei $(C$ and $D$; $\mathrm{H} \& \mathrm{E} \times 200$, arrows). Mild moth-eaten changes seen on nicotinamide adenine dinucleotide (NADH) stain, indicating uneven mitochondrial enzyme activity within the sarcoplasm ( $E$ and F; $\mathrm{NADH} \times 200$ ).

mutations remains to be established through continued follow-up of the known patients ${ }^{6}$ and diagnosis and followup of new patients with CFZS.

\section{Author contributions}

Hadil Alrohaif: manuscript drafting and data analysis and interpretation. Ana Töpf: data analysis and interpretation and critical revision of the manuscript. Teresinha Evangelista: data analysis and interpretation. Monkol Lek: data analysis. Daniel McArthur: study design. Hanns Lochmüller: study design and critical and final revision of the manuscript.

\section{Acknowledgment}

The authors are grateful to the patient reported here for giving them permission to share his data and his photographs. They are also grateful to the Newcastle MRC Centre Biobank for Neuromuscular Diseases. Diagnostic facilities at the John Walton Muscular Dystrophy Research Centre are supported by the Nationally Commissioned Highly Specialised Service
(HSS) for Neuromuscular Diseases (NHS England). The authors thank Dr. Tuomo Polvikoski from The Newcastle upon Tyne Hospitals NHS Foundation Trust for his help in interpreting muscle biopsy images. They also thank Dr. Chiara Marini Bettolo and Dr. Michela Guglieri from the MRC Centre for Neuromuscular Diseases for their help with clinical logistics.

\section{Study funding}

Exome sequencing was supported by funding from the National Human Genome Research Institute of the US National Institutes of Health (Medical Sequencing Program grant U54 HG003067). H.L. is supported by the European Union Seventh Framework Programme (FP7/2007-2013) under grant agreement Nos. 305444 (RD-Connect), 305121 (NeurOmics), and by a Wellcome Trust Pathfinder Award (201064/Z/16/Z).

\section{Disclosure}

Hadil Alrohaif, Ana Töpf, Teresinha Evangelista, and Monkol Lek report no disclosures. Daniel McArthur has served as a consultant and has held stock and/or stock options in 
Goldfinch Bio and has received research support from Biogen and Merck. Hanns Lochmüller has served on the scientific advisory boards of the German Duchenne Parents Project, IRDiRC Interdisciplinary Scientific Committee, German Muscular Dystrophy Network, Myotubular Trust Patient Registry, Action Duchenne Patient Registry, and German Patient Registries on DMD and SMA; has served on the editorial boards of the Journal of Neuromuscular Diseases and Journal of Neurology; has served as a consultant of Roche Pharmaceuticals and Ultragenyx Pharmaceutical Inc; and has received research support from Ultragenyx Pharmaceutical Inc, AMO Pharma, GW Pharma, European Commission, Medical Research Council (MRC), Wellcome Trust, Action Duchenne, Association Francaise Contre les Myopathies, British Heart Foundation, Muscular Dystrophy UK, National Cancer Institute, Spinal Muscular Atrophy Support UK, Jennifer Trust, and Duchenne Parent Project. Full disclosure form information provided by the authors is available with the full text of this article at Neurology.org/NG.

Received November 30, 2017. Accepted in final form February 20, 2018.

\section{References}

1. Millay DP, O'Rourke JR, Sutherland LB, et al. Myomaker is a membrane activator of myoblast fusion and muscle formation. Nature 2013;499:301-305.

2. Gamage DG, Leikina E, Quinn ME, Ratinov A, Chernomordik LV, Millay DP. Insights into the localization and function of myomaker during myoblast fusion.J Biol Chem 2017;292:17272-17289.

3. Luo W, Li E, Nie Q, Zhang X. Myomaker, regulated by MYOD, MYOG and miR140-3p, promotes chicken myoblast fusion. Int J Mol Sci 2015;16:26186-26201.

4. Zhang W, Roy S. Myomaker is required for the fusion of fast-twitch myocytes in the zebrafish embryo. Dev Biol 2017;423:24-33.

5. Millay DP, Sutherland LB, Bassel-Duby R, Olson EN. Myomaker is essential for muscle regeneration. Genes Dev 2014;28:1641-1646.

6. Di Gioia SA, Connors S, Matsunami N, et al. A defect in myoblast fusion underlies Carey-Fineman-Ziter syndrome. Nat Commun 2017;8:16077.

7. Telegrafi A, Webb BD, Robbins SM, et al. Identification of STAC3 variants in nonNative American families with overlapping features of Carey-Fineman-Ziter syndrome and Moebius syndrome. Am J Med Genet A 2017;173:2763-2771. 


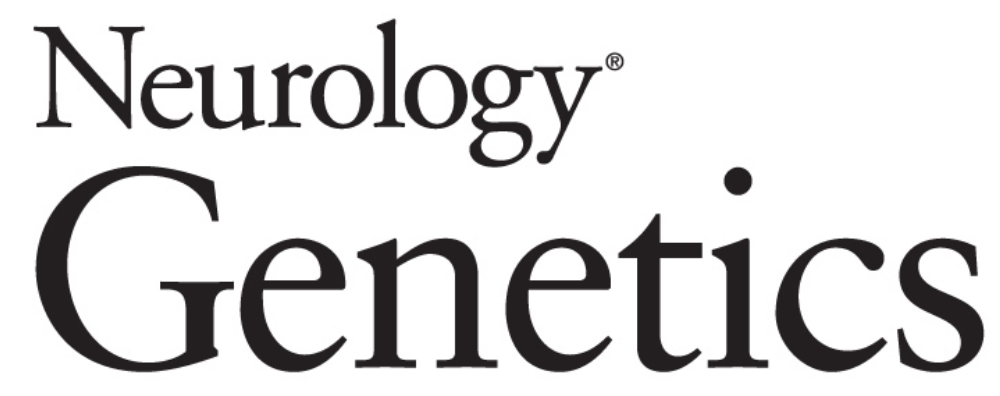

\section{Whole-exome sequencing identifies mutations in MYMK in a mild form of Carey-Fineman-Ziter syndrome}

Hadil Alrohaif, Ana Töpf, Teresinha Evangelista, et al. Neurol Genet 2018;4;

DOI 10.1212/NXG.0000000000000226

\section{This information is current as of March 19, 2018}

\section{Updated Information \&} Services

References

\section{Subspecialty Collections}

Permissions \& Licensing

\section{Reprints}

including high resolution figures, can be found at: http://ng.neurology.org/content/4/2/e226.full.html

This article cites 7 articles, 2 of which you can access for free at: http://ng.neurology.org/content/4/2/e226.full.html\#\#ref-list-1

This article, along with others on similar topics, appears in the following collection(s):

\section{All Genetics}

http://ng.neurology.org//cgi/collection/all_genetics All Neuromuscular Disease http://ng.neurology.org//cgi/collection/all_neuromuscular_disease

Information about reproducing this article in parts (figures,tables) or in its entirety can be found online at:

http://ng.neurology.org/misc/about.xhtml\#permissions

Information about ordering reprints can be found online: http://ng.neurology.org/misc/addir.xhtml\#reprintsus

Neurol Genet is an official journal of the American Academy of Neurology. Published since April 2015, it is an open-access, online-only, continuous publication journal. Copyright Copyright @ 2018 The Author(s). Published by Wolters Kluwer Health, Inc. on behalf of the American Academy of Neurology.. All rights reserved. Online ISSN: 2376-7839.

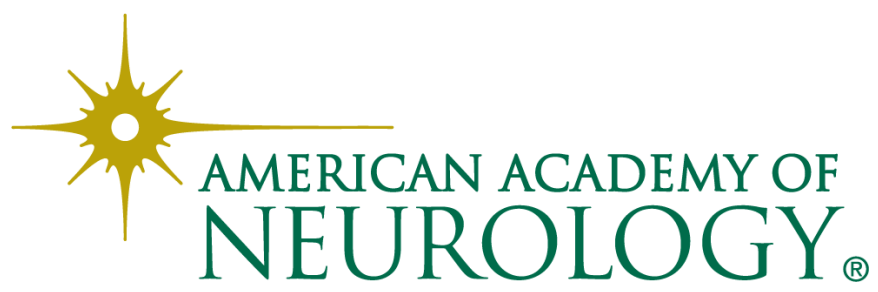

